\title{
Emotional Intelligence and Academic Achievement of Adolescents
}

\author{
Dr.Lopamudra Dash ${ }^{1}$, Chinmay Bairiganjan ${ }^{2}$ \\ ${ }^{1}$ Lecturer in Education, ${ }^{2}$ Research scholar, NKC CTE ANGUL, Odisha
}

\begin{abstract}
This paper is an endeavor to examine relationship between Emotional intelligence and academic achievement of adolescents.It also studies Emotional intelligence and academic achievement levels of boys and girls.Sample for the study includes 80 students (40 boys and 40 girls) of class 9 in Puri district of Odisha.The data were analyzed with the help of product moment correlation. The results revealed that there is positive correlation between Emotional intelligence and academic achievement.
\end{abstract}

Keywords_-Emotional intelligence, Academic Achievement, Adolescent

\section{INTRODUCTION:}

"EQ helps achieve a sense of mission and ensure true development."

\section{-Narendra Modi}

Emotion can make us richer by knowing, educating and giving them 'intelligence.' Emotional intelligence is the capacity for recognizing our own feelings and of others, for motivating and for managing emotions well in us and in our relationships. We are gradually moving towards a knowledge based society which believe on the strength of information. Emotional Intelligence allows us to think more creatively and use our emotions to solve day-to-day problems. The effect of growing stress on student's life and achievement caused by physiological, psychological and environmental demands requires serious attention. The primary objective of this research was to study Emotional Intelligence and academic achievement of Adolescent students of Puri district.

\section{NEED AND SIGNIFICANCE OF THE STUDY:}

In the modern world, education is getting widened and there is a huge competition among students to excel. Students feel difficult to control their emotions in order to face different situations in school life. It is imperative to manage the stress and strain to keep pace with the demands of the modern world. The way of managing emotions is vital for better performance. Even after they got into their desired field, their academic achievement is not at all adequate. Success in academics can be forecasted more by emotional measures. Parent and teachers focus always on academic performance through nurturing intelligence and they give less importance to their emotions. Emotions of a student can affect him in many ways. Emotional intelligence can enrich their learning proficiency and make them efficient achievers.The study will be significant enough in development of teaching strategies for developing emotional intelligence, in curriculum development, preparing instructional material for teacher education programme, especially at the secondary stage of education in the state.

\section{REVIEW OF RELATED LITERATURE:}

It is observed from the reviewed studies on emotional intelligence that most of the researcher's findings on emotional intelligence have contradiction. However, emotional intelligence is considered as an important 
DOI: 10.17148/IARJSET.2021.88103

construct to understand human behaviour and future success in life. A substantial number of studies are found concentrating on the relationship between EI and Academic achievement. To study the level of emotional intelligence and academic achievement of the adolescent students and to know the relations of emotional intelligence with academic achievement constitute the base of the present investigation.

Ana Costa, Luísa Faria(2020) conducted study on "Implicit theories of emotional intelligence, ability and traitemotional intelligence and academic achievement".The results confirmed the direct effect of EI (ability and trait EI) on students' Academic achievement.Suleman Q, Hussain I, Syed MA, Parveen R, Lodhi IS, Mahmood Z (2019) Studied association between emotional intelligence and academic success among undergraduates.The findings revealed that there was a strong positive relationship between emotional intelligence and academic success.SathyamurthiKaribeeran,Shefali Mohanty(2019) studied Emotional intelligence among adolescents and results revealed that all factors including family,school and media help to improve EI among adolescents..GiuliaBallarotto, Barbara Volpi, Eleonora Marzilli, Renata Tambelli(2018) conducted a study on adolescents internet Abuse and found that girls had used more internet than boys.Rajkrishna Ravikumar, O P Rajoura and Manjeet S Bhatia(2017) studied Emotional intelligence among postgraduate Medical students in Delhi and found that EI increase with Age and experience. Unnikrishnan et al (2015) designed a study to assess the association of emotional intelligence (EI) with academic performance among medical students.They found a significant association between EI and academic performance and concluded that efforts must be made to include the concept of EI into the medical curriculum.Chamundeshwar (2013) investigated the emotional intelligence and academic achievement of students at the higher secondary level. Results revealed a positive and significant correlation between emotional intelligence and academic achievement among the students. Singh and Praveen (2010) studied the relationship between social maturity and academic achievement of high school students The results indicated that there were no significant differences between the academic achievement of boys and girls.

\section{STATEMENT OF THE PROBLEM:}

The statement under the present study is stated as:

\section{"Emotional Intelligence and Academic Achievement of Adolescents"}

\section{OBJECTIVES OF THE STUDY:}

The study was conducted keeping in the view the following objectives:

$\star \quad$ To study the Emotional Intelligence of adolescents of class IX students in Puri district.

$\star \quad$ To study the Academic achievement of adolescents of class IX students in Puri district.

$\star \quad$ To compare Emotional Intelligence of adolescents in relation to gender (Boys and Girls).

$\star \quad$ To compare Academic achievement of adolescents in relation to gender (Boys and Girls).

$\star \quad$ To compare the relationship between Emotional intelligence and academic achievement of Adolescents.

\section{HYPOTHESES OF THE STUDY:}

$\boldsymbol{H}_{01}$ There is no significant difference between boys and girls of class-IX adolescents with respect to Emotional Intelligence.

$\boldsymbol{H}_{02}$ There is no significant difference between boys and girls of class-IX adolescents with respect to Academic achievement.

$\boldsymbol{H}_{03}$ There is no significant relationship between Emotion intelligence and Academic achievement of class-IX adolescents. 


\section{International Advanced Research Journal in Science, Engineering and Technology}

Vol. 8, Issue 8, August 2021

DOI: 10.17148/IARJSET.2021.88103

\section{DELIMITATIONS OF THE STUDY:}

As it was required to complete the study within a short period of time, so the study had following delimitations:

$\star \quad$ The study was limited to adolescents of Kanas block of Puri district only.
$\star \quad$ The study was limited to class IX adolescents only.
$\star \quad$ The study was limited to 80 adolescents of 4 Govt. secondary schools only.

\section{OPERATIONAL DEFINITIONS:}

Emotional Intelligence-It is an ability, capacity or skill to perceive, assess and manage the emotions of one's self, of others and of groups. Here 4 areas of EI were measured: Intra personal awareness(Knowing about one's own emotions),Inter personal awareness(Knowing about others emotions),Intra personal Management(Managing own emotions),Inter personal Management(Managing others emotions).

Academic Achievements: Class-VIII annual Test scores of class-IX students.

Adolescents-class Ix students.

Secondary school- The school which includes the students of class-IX and X.

\section{DESIGN OF THE STUDY:}

Researcher followed the "Correlational research design" for the study.

\section{SAMPLE:}

All the adolescent students studying in class ix of Kanas block in Puri district constitute as population for the present study.Though,it is not possible to study the entire population.By considering this fact, twenty (20) students both boys and girls from each selected schools was selected.Finally in the present study,a sample of eighty (80) students was selected from four Govt. secondary schools i.e. 40 boys and 40 girls on the basis of cluster through random sampling.

\section{Tools Used}

A standardized tool "Emotional Intelligence Inventory" developed by Dr. S.K. Mangal and Mrs. SubhraMangal and academic achievement score card were used for collection of data.

\section{PROCEDURE OF DATA COLLECTION:}

The investigator himself moved from school to school met the Headmaster and students gave the inventory for response.

\section{DATA ANALYSIS AND DATA INTERPRETATION:}

In the present study the investigator has used simple statistics devices like mean and standard deviation. Data are represented in tabular form. To know the significance level of boys and girls 't' test was used. Calculated value has found less than table value. Hence the null hypotheses are accepted. The investigator has calculated ' $r$ ' value to know relationship between EI and AA by using product moment correlation.

\section{1-Comparison of EI scores of each category of Boys and Girls}

\begin{tabular}{|l|l|l|l|l|l|l|}
\hline Category & A & B & C & D & E & Total \\
\hline $\begin{array}{l}\text { No.of boys } \\
\text { (in\%) }\end{array}$ & 2.5 & 5 & 35 & 52.5 & 5 & $100 \%$ \\
\hline
\end{tabular}


International Advanced Research Journal in Science, Engineering and Technology

Vol. 8, Issue 8, August 2021

DOI: $10.17148 /$ IARJSET.2021.88103

\begin{tabular}{|l|l|l|l|l|l|l|}
\hline $\begin{array}{l}\text { No.of girls } \\
\text { (in\%) }\end{array}$ & Nil & 5 & 57.5 & 27.5 & 10 & $100 \%$ \\
\hline
\end{tabular}

From the above it is clear that boys and girls have average level of Emotional Intelligence.

\section{2-Comparison of Academic Achievement of each Grades of Boys and Girls}

\begin{tabular}{|l|l|l|l|l|l|l|l|l|}
\hline Grades & $\mathbf{A}_{\mathbf{1}}$ & $\mathbf{A}_{\mathbf{2}}$ & $\mathbf{B}_{\mathbf{1}}$ & $\mathbf{B}_{\mathbf{2}}$ & $\mathbf{C}$ & $\mathbf{D}$ & $\mathbf{E}$ & Total \\
\hline $\begin{array}{l}\text { No.of } \\
\text { boys(in\%) }\end{array}$ & 7.5 & 22.5 & 17.5 & 20 & 22.5 & 2.5 & 7.5 & $100 \%$ \\
\hline $\begin{array}{l}\text { No.of } \\
\text { girls(in\%) }\end{array}$ & Nil & 12.5 & 22.5 & 37.5 & 17.5 & 7.5 & 2.5 & $100 \%$ \\
\hline
\end{tabular}

From the above it is clear that most of the boys have excellent and above average scores .Most of the girls have good scores

3-Significant difference between Boys and Girls With respect to Emotional Intelligence

\begin{tabular}{|c|c|c|c|c|c|c|}
\hline Gender & $\mathbf{N}$ & Mean & SD & $\mathbf{S E}_{\mathrm{D}}$ & $\begin{array}{l}\mathrm{t} \\
\text { Value }\end{array}$ & Significance \\
\hline Boys & 40 & 63.775 & 9.35 & \multirow{2}{*}{2.01} & \multirow{2}{*}{1.07} & \multirow{2}{*}{$\begin{array}{l}\text { Not Significant At } \\
0.05 \text { Level }\end{array}$} \\
\hline Girls & 40 & 61.625 & 8.72 & & & \\
\hline
\end{tabular}

Since the calculated " $t$ " value is less than the table value at $5 \%$ level of significance, so the null hypothesis is accepted.No significant gender differences were found in Emotional intelligence.The above findings draws support from the findings of Farheen Nasir and Seema Munaf(2011). However Mahmood A. Khan and Nisar A. Bhat (2013) found higher level of Emotional intelligence of boys than girls.

4-Significant difference between boys and girlsWith respect to academic achievement

\begin{tabular}{|c|c|c|c|c|c|c|}
\hline Gender & $\mathbf{N}$ & Meanscore & SD & $\mathbf{S E}_{\mathbf{D}}$ & $\begin{array}{l}\mathbf{t} \\
\text { value }\end{array}$ & Significance \\
\hline Boys & 40 & 67.55 & 16.0 & \multirow{2}{*}{3.13} & \multirow{2}{*}{0.80} & \multirow{2}{*}{$\begin{array}{l}\text { Not } \\
\text { significant } \\
\text { at } 0.05 \text { level }\end{array}$} \\
\hline Girls & 40 & 65.025 & 11.7 & & & \\
\hline
\end{tabular}

Since the calculated " $\mathrm{t}$ " value is less than the table value at 5\% level of significance, so the null hypothesis is accepted.No significant difference was found between boys and girls so far as their academic achievements are concerned.The above findings draws support from the findings of Shabir Ahmad Bhat and Yashpal Netragaonkar(2014). However Amit Abuja(2016) found higher academic scores of girls than boys. 


\section{International Advanced Research Journal in Science, Engineering and Technology}

Vol. 8, Issue 8, August 2021

DOI: 10.17148/IARJSET.2021.88103

5-Significant relationship between Emotional Intelligence and academic achievement

\begin{tabular}{|l|l|l|l|}
\hline Variable & $\mathbf{N}$ & $\begin{array}{l}\mathbf{r} \\
\text { Value }\end{array}$ & Correlation \\
\hline Emotional Intelligence & 80 & 0.306 & $\begin{array}{l}\text { Positive } \\
\text { Correlation } \\
(+\mathrm{Ve})\end{array}$ \\
\hline AcademicAchievement & 80 & & \\
\hline
\end{tabular}

From the above it is observed that the correlation value (r) obtained through product moment correlation method was 0.306.It shows positive correlation between Emotional Intelligence and academic achievement. Here the null hypothesis is rejected.The above findings draws support from the findings of Nicolas,Maria and Natalie(2020),Mac Cann et al (2019),Svetlana(2007) and Abisamra(2000). However F LotfiKashani, A LotfiAzimi and ShVaziri(2012) found no significant relation between emotional intelligence and academic achievement in a correlation study.

\section{RESULTS AND DISCUSSION:}

Results of the present study indicated that students in secondary school in Puri portray average level of emotional intelligence.They are less affected by negative affects such as anxiety,anger and frustration in performing academic tasks. This may also explains their average academic performance.Gender difference in relation to Emotional intelligence and academic achievement indicated that there is no significant difference between boys and girls.Both are equally aware of Emotional state.Students who have the ability to regulate their negative affect associated with school tasks often perceive more academically competent and vice versa.It is also revealed that Emotional intelligence had a significant correlation with academic achievement.This means a student who is adept in emotional intelligence could use such skill to manage stress and anxiety associated with examination.Further ability to show interpersonal skills may help students to seek academic help from teachers,peers and resource persons.

\section{FINDINGS OF THE STUDY:}

The following main findings have emerged as an outcome of the present investigation:

1. It is found that most of the adolescents have average level of Emotional intelligence.

2. It is also found that most of the adolescents have Good academic performance.

3. There is no significant difference in Emotional intelligence of adolescent girls and boys.

4. There is no significant difference in academic achievement of adolescent boys and girls.

5. There is positive relationship between Emotional Intelligence and academic achievement of adolescents.

\section{CONCLUSION:}

Realizing the reality of emotional intelligence, the curriculum of education right from primary to tertiary education should be reviewed by considering the role of emotional intelligence. A paradigm shift in the system of education together with professionalism of teacher education is the need of the hour. The policy-maker of education should arrange the liberty and an approach as well to firmly support, to ensure the balance of national education system from the aspect of emotional and cognitive intelligence. 


\section{International Advanced Research Journal in Science, Engineering and Technology}

Vol. 8, Issue 8, August 2021

\section{DOI: 10.17148/IARJSET.2021.88103 \\ REFERENCES}

1. Mattingly, v.,\&Kraiger, K.(2019) Can emotional intelligence be trained? A meta-analytical investigation.Human resource management review,29,140-155.http://dx.doi.org/10.1016/j.hrmr.2018.03.002

2. P.A.,Dunkel,C.S., \&petrides,K.V.(2017).overlap between the general factor of personality and Emotional Intelligence: A metaanalysis.psychological Bulletin,143,36-52.http://dx.doi.org/10.1037/bul0000078.

3. Malik, S. Z., \& Shahid, S. (June 2016, Vol. 38).Effect of Emotional Intelligence on Academic Performance among Business Students in Pakistan. Bulletin of Education and Research, 197-208.

4. Seng, N. L., Hanafi, Z., \&Taslikhan, M.(Volume 2; Issue 3; March 2016). Influence of Emotional Intelligence on Students' Academic Achievements. International Journal of Humanities and Social Science Research, 41-46.

5. Hossein, J., Shahidi, R., Elhamifar, A., \&Khademi, H. (2015). Examine the Relationship of Emotional Intelligence and Creativity with Academic Achievement of Second Period High School Students. World Journal of Neuroscience, 275-281.

6. Roy, B., Sinha, R., \& Suman, S. (April 2013).Emotional Intelligence And Academic Achievement Motivation Among Adolescents:A Relationship Study. Journal of Arts, Science \& Commerce, 23-27.

7. Subramanyam, K. (2011): 'Impact of emotional intelligence and study skills of high school students.' Edutracts, February, 2011, Vol. 10, No. 6. Pp 36-38.

8. Vijayakumari K. (2010): Some Correlates of Academic Achievement of Secondary School Students. (Edutracks, January, 2010; Vol. 9, No. 5 pp 39).

9. Mangal, S. K. \& Mangal S. (2009). Manual for Mangal Emotional Intelligence Inventory. National Psychological Corporation, Agra.

10. Berrocal, D. and Fernandaz, R.P. (2008) Emotional Intelligence Journal of research in Educational Psychology, No. 15, Vol. 6(2), 2008, pp $421-436$.

11. Akhil S S; Anakha E; Sylaja H. "Psychosocial Correlates of Young Adult Students". International Research Journal on Advanced Science Hub, 3, Special Issue 7S, 2021, 70-73.

12. KshitijJethe; Aniket Hedau; Rohit Kolankar; Sahil Dhoble; DivyanshuMataghare. "EduAR- an AR based Learning Application". International Research Journal on Advanced Science Hub, 3, Special Issue ICITCA-2021 5S, 2021, 44-47.

13. Segal J. (2008). The Language of Emotional Intelligence. McGraw Hill, New York.

14. Thakkar, J., (2007). Construction and Standardization of Emotional Intelligence Test for the Students of the Secondary Schools of Gujarat State, unpublished Ph. D.Thesis, Gujarat University, Ahemdabad.

15. Dhawan, A. (2006) A Study, of Emotional Intelligence,Cognitive Style and Personality Types of Academically Talented and Average Students. Ph.D. Thesis in Education,Chandigarh: Punjab University

16. Singh Y. K., (2006). Fundamental of research methodology and statistics.New Age International (P) Ltd. Publishers, New Delhi.

17. Devi, U.L. and Uma, M. (2005) Relationship between the dimensions of emotional intelligence of adolescents and certain personal social variables. Indian Psychological Review 64, 01, 14-16.Incarnate Word.

18. Lekha, V. (2005) A study of emotional maturity of adolescents in relation to Cognitive and Non-cognitive variables, Ph.D. thesis, Punjab University,Chandigarh.

19. Kothari, C. R., (2004). Research Methodology. New Age International (P) Limited, Publishers, New Delhi.

20. Sanwal, V. (2004). Emotional Intelligence: The Indian Scenario, New Delhi, Indian publisher Distributers. Torrance, E.P.: Guiding Creative Talent, Prentice Hall of India Pvt. Ltd. New Delhi.

21. Parker, et al. (2003). Emotional intelligence and academic success: examining the transition from high school to university. Personality and Individual Difference, 36, 163-172. Retrieved from http://www.sciencedirect.com.

22. www.renaissancelawyer.com/emotional_intelligence.htm

23. www.talentsmart.com/about/emotional-intelligence.php

24. www.unh.edu/emotional_intelligence

25. www.youtube.com

26. www.wadsworth.com/psychology_d/templates/student_resources/workshops/res_method/sampling/

27. http://en.wikipedia.org/wiki/emotional intelligence 